\title{
Abnormal distribution of c-myc oncogene product in familial adenomatous polyposis
}

\author{
V S.UNDARESAN, ${ }^{*}$ I C FORGACS $\ddagger$ D G D WIGHT, ${ }^{*}$ BEVERLY WILSON,* \\ G I EVAN, $\dagger$ J V WATSON§
}

From the §Medical Research Council Clinical Oncology Unit, The Medical School, Cambridge, the Departments of *Histopathology, and $\ddagger$ Gastroenterology, Addenbrooke's Hospital, Cambridge, and the $\nmid$ Ludwig Institute for Cancer Research, The Medical School, Cambridge

SUMMARY Monoclonal antibodies raised by synthetic peptide immunisation were used to determine the distribution of the protein product of the c-myc gene by immunocytochemical staining of archival wax embedded material from patients with familial adenomatous polyposis. Polyps from 18 cases of familial adenomatous polyposis, 10 of whom had developed malignant change, and 30 normal control colonic biopsy specimens were examined. A consistent staining pattern was observed in normal mucosa; nuclear staining in the basal proliferative zone; mixed nuclear and cytoplasmic staining in the maturation zone; and cytoplasmic localisation in the surface mature zone. In contrast, the polyps and carcinomata showed a mixed pattern of cytoplasmic and nuclear localisation in the basal proliferative zone with nuclear persistence throughout the crypts to the surface mature zone. This abnormal distribution of the c-myc oncogene product may have a role in the evolution of polyps and their subsequent malignant transformation into familial adenomatous polyposis.

Familial adenomatous polyposis, also known as polyposis coli or familial polyposis, is inherited by an autosomal dominant gene. ${ }^{1}$ Numerous adenomatous polyps develop throughout the large intestine and unless treated by radical surgery the subsequent development of colonic carcinoma is inevitable. ${ }^{23}$ The development of familial adenomatous polyposis is consistent with the multistep theory of carcinogenesis. ${ }^{4}$ The essential first step is an inherited genetic defect leading to multiple polyps, following which malignant transformation takes place in some of the polyps. Little is known, however, about the nature of the gene defect or the molecular events entailed in the transformation of the colonic mucosa to adenomatous polyps and then to carcinoma. DNA synthesis occurs only in the lower portions of the crypts of Lieberkuhn in normal colonic mucosa,${ }^{5}$ but studies in patients with familial adenomatous polyposis have shown that synthesis of DNA continues throughout the crypt and even in some areas of histologically normal tissues remote from the adenoma. ${ }^{6}$

An increasing body of evidence suggests that dereg-

Accepted for publication 2 June 1987 ulation of cellular proto-oncogenes (c-onc), some of which have DNA sequence homology with transforming RNA tumour viruses, ${ }^{78}$ may play a part in malignant transformation in a variety of human tumours. ${ }^{9-18}$ The protein products of some of these genes have a role in the transmission and transduction of growth regulatory signals. ${ }^{19-23}$ The product of the c-myc gene, $\mathrm{p} 62^{\mathrm{c}-\mathrm{myc}}$, may also play a part in cell cycle regulation ${ }^{24-31}$ and hence in proliferation control, and possibly in differentiation ${ }^{32} 33$ through its participation in DNA synthesis. ${ }^{34}$ The c-myc oncogene has been implicated in the pathogenesis of a number of human tumours. In Burkitt's lymphoma it is translocated, ${ }^{35}$ it is amplified in human lung cancer cell lines ${ }^{11}$ and in cervical cancer, ${ }^{17}$ and it is rearranged and expressed in haemopoetic malignancies. ${ }^{16} 18$

The c-myc gene product has been detected in both colonic $^{36}$ and testicular cancer, ${ }^{37}$ using immunoperoxidase techniques with a monoclonal antibody and fluorescence methods have been developed for its quantitation using flow cytometry. ${ }^{38-41}$ In this study the distribution and abundance of $\mathrm{p} 62^{\mathrm{c}-\mathrm{myc}}$ was assessed by immunohistological analysis of colonic tissue from patients with familial polyposis coli. 


\section{Material and methods}

Each of the total colectomy specimens from the 18 patients who underwent surgical treatment for familial adenomatous polyposis at Addenbrooke's Hospital over a 22 year period (1964-1986) were included in the study. Of these 18 patients, there were eight men and 10 women whose age range was $22-77$ years at time of surgery. Ten of the patients (three men and seven women, age range 22-74) had evidence of colonic malignant disease) at the time of operation. After surgery the resected specimens were fixed in $10 \%$ buffered formalin and representative sections were wax embedded and material not used was stored in the archives of the department of pathology, Addenbrooke's Hospital.

Thirty normal colonoscopic or sigmoidoscopic biopsy specimens were taken from patients attending the gastroenterology clinic for investigation of bowel symptoms, including irritable bowel syndrome. These were prepared identically and used as control material.

\section{ANTIBODIES AGAINST THE C-MYC PROTEIN}

Full details for the production and characterisation of the antibodies are given elsewhere. ${ }^{42}$ Briefly, the DNA base sequence of the cloned gene was used to determine the amino acid structure of the protein. Synthetic peptides were constructed to regions predicted to be hydrophilic and hence likely to be exposed on the surface of the complete molecule. Mice were immunised with the peptides to produce a number of monoclonal antibodies which immunoprecipitate a 62000 dalton protein identifiable with the c-myc product. ${ }^{42}$ One antibody, MYC 1-6E10, was raised to the 18 amino acid sequence (D-peptide) from residues 171-188. The second, MYC-CT14, was raised to a 32 amino acid peptide (G-peptide) corresponding to the carboxy terminus of $\mathrm{p} 62^{\mathrm{c}-\mathrm{myc}}$ (residues 408-439).

\section{IMMUNOHISTOLOGY}

Sections of $4 \mu \mathrm{m}$ were cut from normal colonic biopsy specimens and from at least two separate polyps from each case of familial adenomatous polyposis. In the 10 cases with colonic malignant disease a representative section was also cut from the adenocarcinoma. The sections were mounted on glass slides, dewaxed in xylene, and rehydrated in serial dilutions of alcohol. The sections were then covered in 3\% hydrogen peroxide for 10 minutes and washed in $10 \%$ bovine serum albumin (BSA) in phosphate buffered saline (PBS) for 10 minutes. After draining excess buffer from the slides the MYC 1-6E10 antibody was added to the sections for 45 minutes at a concentration of $4 \mu \mathrm{g} \mathrm{ml} /-1$. MYC-CT14 was used in several duplicate sections of normal mucosa at a concentration of $100 \mu \mathrm{g} \mathrm{ml} /-1$. This antibody has been found to give fluorescence signals which were four-fold lower than those with MYC 1-6E10 in flow cytometric studies, ${ }^{41}$ hence a higher concentration was used. The slides were then washed in PBS for five minutes at room temperature and a peroxidase conjugated rabbit antimouse serum (Dakopatts P260) diluted 1/100 was added and incubated at $20^{\circ} \mathrm{C}$ for 30 minutes. The slides were then washed in PBS and the peroxidase label visualised by incubation in a solution of $0.5 \mathrm{mg}$ $\mathrm{ml} /-1$ diaminobenzidine tetrahydrochloride plus $0.03 \% \mathrm{w} / \mathrm{v} \mathrm{H}_{2} \mathrm{O}_{2}$ for 10 minutes. The sections were then washed in running tap water and light Harris's haematoxylin staining was carried out. Negative controls were prepared as in previous studies by blocking the MYC 1-6E10 antibody with the D-peptide used as the immunogen. ${ }^{2636-41}$ The binding of this antibody was not blocked by preincubation with the G-peptide corresponding to the carboxy terminus of the c-myc protein.

Each section was examined by two pathologists independently. The crypts were divided into three zones where zone A corresponded to the basal proliferative zone and zone $\mathrm{C}$ to the surface mature epithelium (fig 1). Zone B, the intermediate maturation zone, was between zones $\mathrm{A}$ and $\mathrm{C}$.

The distribution and intensity of $p 62^{c-m y c}$ within cells was graded according to whether the pattern of staining was exclusively nuclear $(\mathrm{N})$, exclusively cytoplasmic (C), or mixed (M) (fig 2). The intensity was graded as 0 no staining; + minimal staining; ++ moderate staining; or +++ heavy staining. The staining characteristics were studied in normal mucosa, polyps, mucosa adjacent to polyps, and in adenocarcinomas.

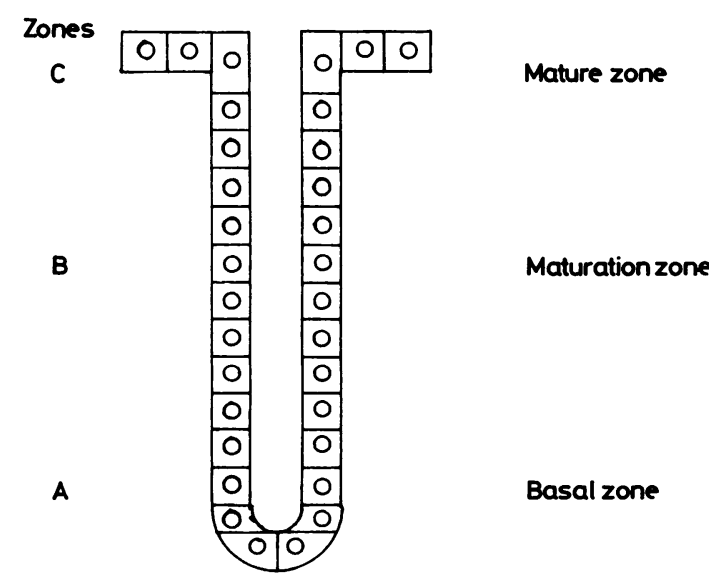

Fig 1 Zones of crypts of Lieberkuhn. 

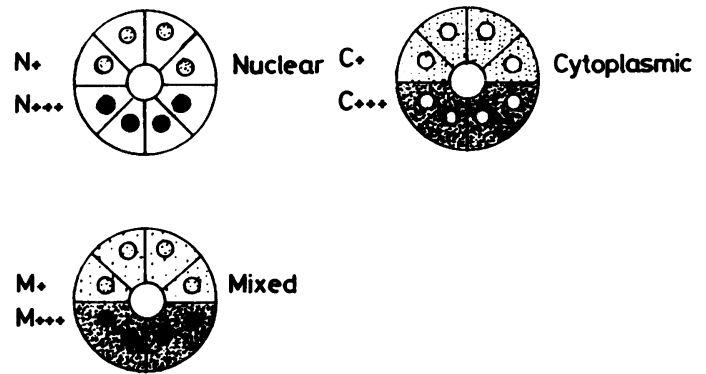

Fig 2 Pattern of staining of glands.

\section{Results}

All results were obtained with the MYC 1-6E10 antibody. Duplicate slides of normal mucose stained with MYC-CT14 gave identical results although the background was a little higher. MYC-CT14 was not used for all sections as considerably more of the reagent was required.

\section{NORMAL MUCOSA}

Staining patterns were essentially identical in all sections with exclusive cytoplasmic staining of the mature zone (zone $\mathrm{C}$ ), mixed nuclear and cytoplasmic staining in the maturation zone (zone B), and exclusive nuclear staining in the proliferative zone (zone A), (figs $3 a$ and $4 a$ ).

\section{NEOPLASTIC TISSUE}

In polyps and carcinomas the orientation was not always ideal, hence the zones were arbitrarily defined as zone $\mathbf{A}$ corresponding to the lamina propria immediately above the muscularis mucosa and zone $\mathrm{C}$ as the surface epithelium which was often ulcerated in the carcinomas. The "intermediate" zone B was between zones $\mathrm{A}$ and $\mathrm{C}$. The consistency of staining patterns, including both the intensity and subcellular location, were more variable than seen in the normal mucosa.

\section{ADENOMATOUS POLYPS}

In contrast to the normal controls, in 27 of 36 polyps from 18 cases nuclear staining was retained in the surface epithelium (zone C). In nine of these 27 polyps there was mixed nuclear and cytoplasmic staining. At the base of the crypts (zone A) normal nuclear staining was seen in all but three polyps. Of these 33 polyps, mixed cytoplasmic and nuclear staining was present in 12. The mucosa adjacent to the polyps was essentially the same as that of normal controls. No staining was seen in the normal mucosa adjacent to polyps in three separate cases (table 1, figs $3 \mathrm{~b}, 4 \mathrm{~b}$, and 4c). ${ }^{141718}$

\section{CARCINOMAS}

As in the polyps, and again contrasting with controls, there was nuclear staining of the malignant surface epithelium (zone $\mathrm{C}$ ) in all but one of the 10 cases. Six of these nine cases were accompanied by cytoplasmic staining. In contrast to the controls, there was cytoplasmic staining in the proliferative zone (zone $\mathrm{A}$ ) in eight of 10 cases. This was accompanied by nuclear staining in four of these eight. Nuclear staining resembling that seen in controls was seen in two cases in

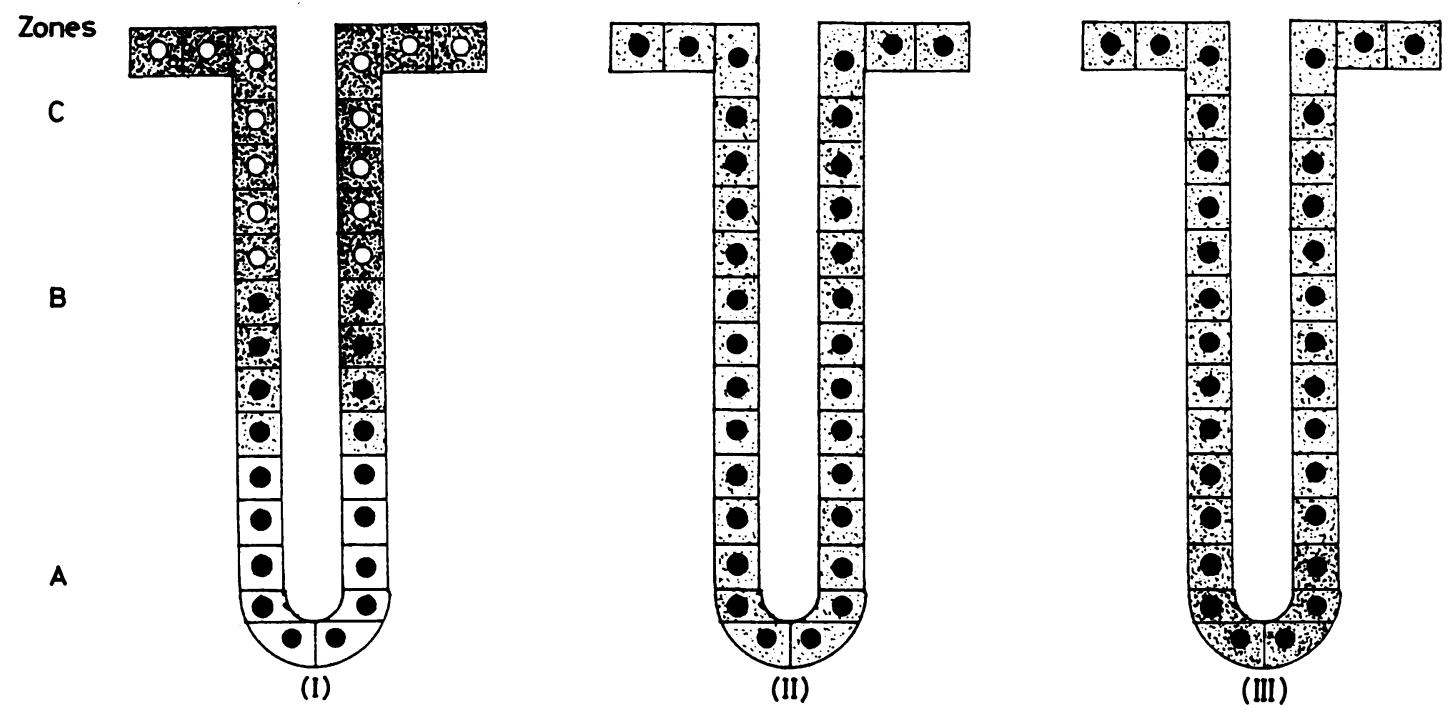

Fig 3 Diagrammatic representation of results. 


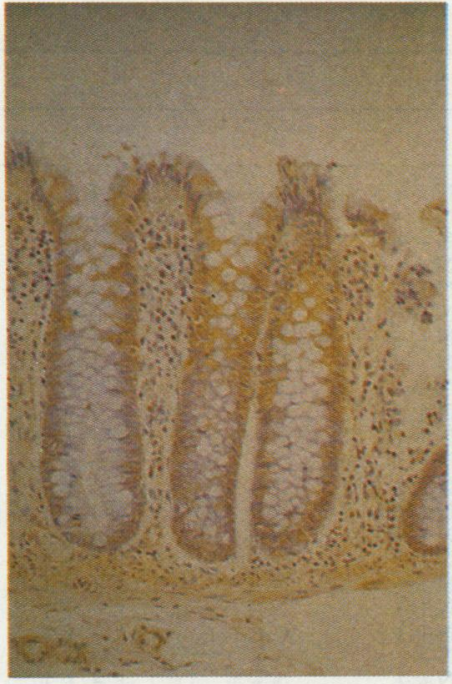

(a)

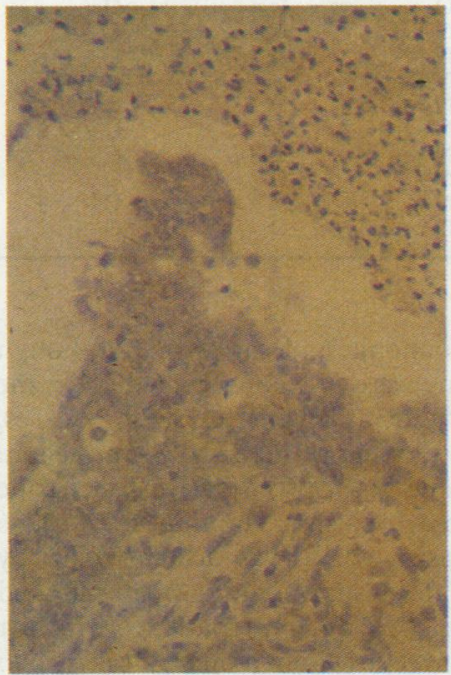

(d)

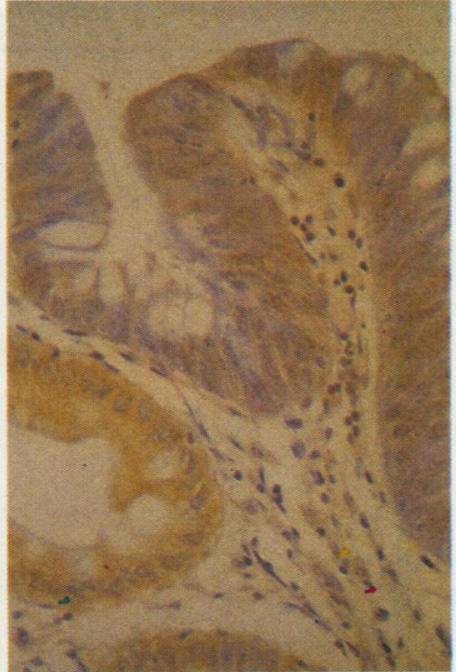

(b)

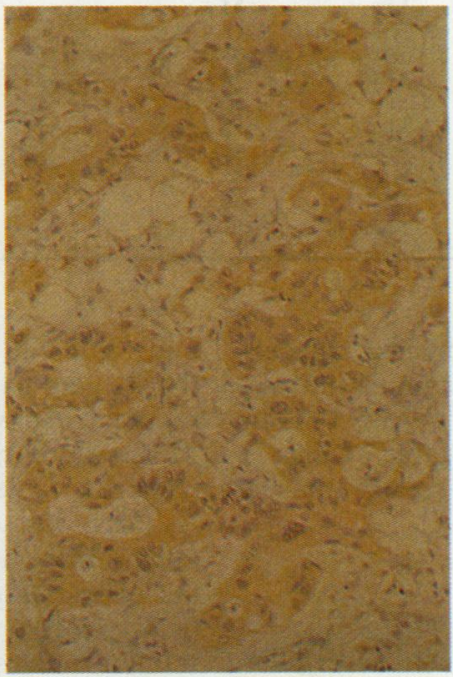

(e)

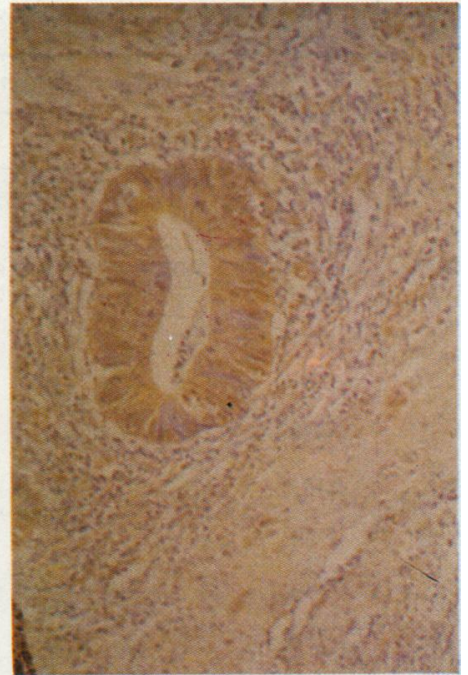

(c)

Fig 4 a Normal large bowel pattern of staining with MYC 1-6E10. (b) Surface of adenomatous polyp with adjacent normal mucosa showing nuclear and cytoplasmic localisation. (c) Adenomatous gland proliferative zone (zone A) showing nuclear and cytoplasmic localisation. (d) Surface of adenocarcinoma covered by fibrino-purulent material showing exclusively nuclear localisation. (e) Nests of adenocarcinoma above muscularis mucosa showing mixed cytoplasmic and nuclear localisation. 
Table 1 Distribution and abundance of $p 62^{c-m y c}$ in adenomatous polyps and adjacent mucosa

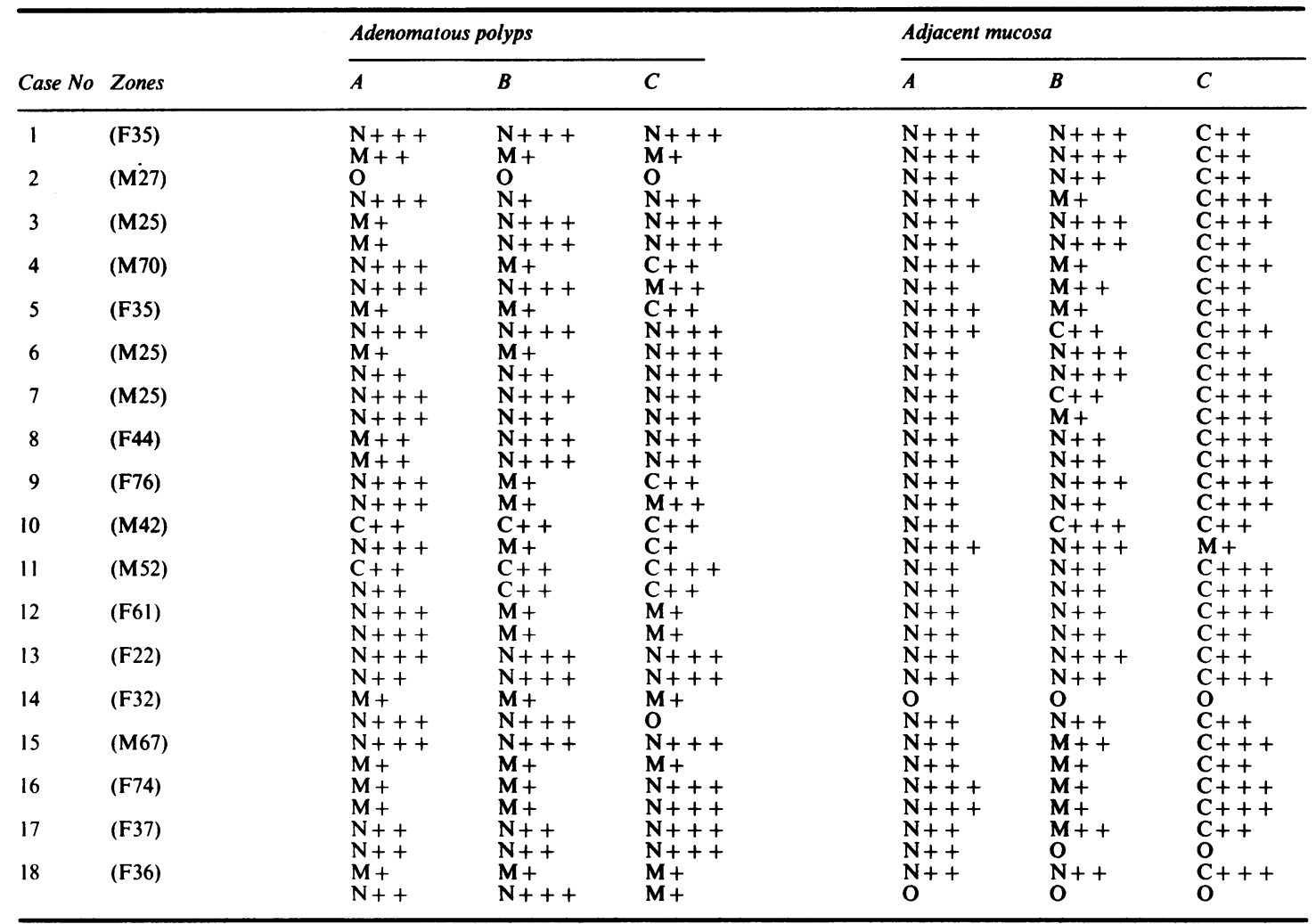

zone A. Where present, the normal mucosa adjacent to the carcinoma showed a normal staining pattern. No normal mucosa was attached to the tumour biopsy specimens in two carcinomas (table 2). Figs 3c and $4 \mathrm{~d}$ show the staining patterns of zone $A$ and the malignant surface epithelium in zone $C$.

\section{Discussion}

This study has shown that expression and subcellular distribution of the c-myc protein product is abnormal in both polyps and carcinoma from patients with familial adenomatous polyposis.

A clear and uniform pattern of $p 62^{c-m y c}$ distribution was seen in normal colonic mucosa where there was moderate to heavy nuclear staining in the base of the crypts with similarly intense cytoplasmic staining at the surface. The intermediate maturation zone showed moderate nuclear or mixed nuclear and cytoplasmic staining. This pattern was also seen in histologically normal mucosa adjacent to adenomatous polyps.

In contrast, the distribution of oncoprotein was quite different in adenoma and carcinoma, although the staining patterns were less consistent than in the normal mucosa. Of the 36 polyps from these 18 cases, 27 showed nuclear staining of the surface epithelium (zone C), while in the basal proliferative zone (zone A) there was some cytoplasmic staining in 14 of 36 polyps from 11 cases which was accompanied by nuclear staining. Cytoplasmic staining predominated in two polyps from two different patients. Nuclear staining of the surface epithelium (zone $\mathrm{C}$ ) was seen in nine of 10 carcinomas, and eight of 10 showed cytoplasmic staining of cells in the basal proliferative zone. This abnormal staining pattern of carcinomas in zones $\mathrm{A}$ and $\mathrm{C}$ included mixed nuclear and cytoplasmic staining. Clearly, the staining patterns in polyps and carcinoma were different compared with those seen in normal mucosa.

Subcellular fractionation in tissue culture cells has shown that $\mathrm{p} 62^{\mathrm{c}-\mathrm{myc}}$ is predominantly nuclear associated. ${ }^{43}$ Although neither the complete tertiary structure nor function of this protein is known, there is evidence that $p 62^{c-m y c}$ plays a part in cell cycle regulation and hence in proliferation control, ${ }^{24-30}$ and 
Table 2 Distribution and abundance of $p 62^{x-m y c}$ in carcinomas and adjacent mucosa

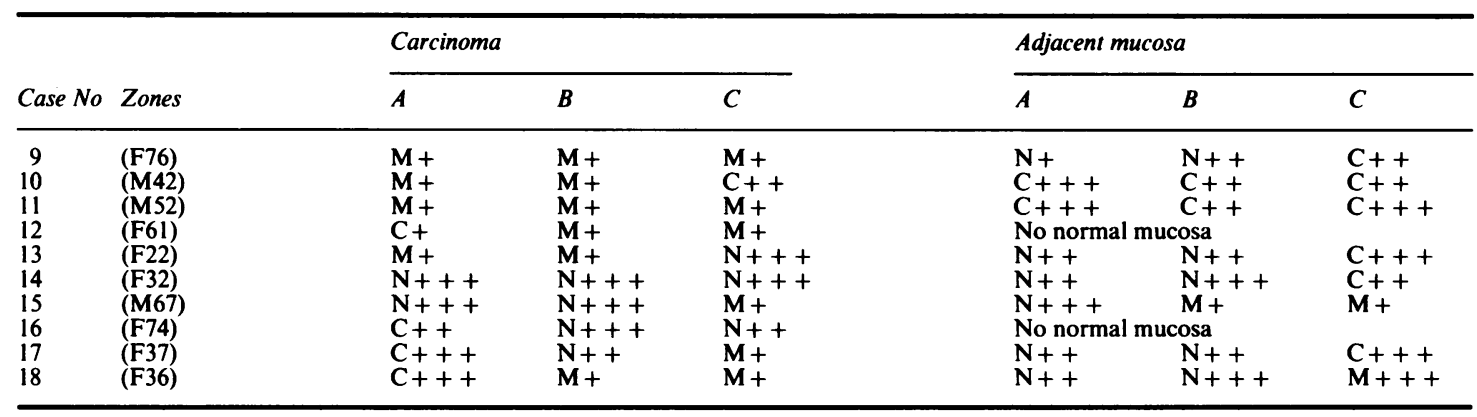

also possibly in differentiation. ${ }^{32} 33$ Recent evidence suggests that $p 62^{c-m y c}$ may be a component of the protein complex with a role in DNA synthesis. ${ }^{31}$ Thus the finding that $\mathrm{p} 62^{\mathrm{c}-\mathrm{myc}}$ was predominantly nuclear associated in the normal crypt base is to be expected as this is the region containing stem cells which constantly repopulate the mucosa. There was, however, a completely consistent pattern in all normal biopsy specimens with increasing cytoplasmic and decreasing nuclear localisation with maturation. At the surface in normal mucosa the staining was exclusively located in the cytoplasm.

Previous studies in colonic mucosa ${ }^{36}$ have also shown cytoplasmic staining using the MYC 1-6E10 antibody. Because of its known nuclear location in tissue culture cells, ${ }^{2743}$ it was suggested that this could have been an artefact induced by the sampling and preparation procedures, as $\mathrm{p} 62^{\mathrm{c}-\mathrm{myc}}$ is very loosely bound in the nucleus. ${ }^{43}$ The staining pattern characterising normal mucosa, however, was seen adjacent to the quite different pattern of adenomatous polyps in the same immunocytochemical preparation (fig 4). Moreover, identical staining patterns were seen in normal mucosa with a second synthetic peptide induced antibody (MYC-CT14) which recognises a different epitope to that of MYC $1-6 \mathrm{E} 10$. A very recently produced third antibody, pan-myc, which recognises a shared epitope on a number of the $m y c$ gene family of proteins was used in a very limited parallel study of only six sections (unpublished data). This also gave a staining pattern in normal mucosa identical with that of MYC 1-6E10 and MYC-CT14. These observations effectively exclude the possibility of artefact, and it is an intriguing possibility that the normal differentiation process may entail the active exclusion of this protein from the nucleus.

Oncogenes are normal constituents of the genome which play a part in the transmission and transduction of growth regulatory signals. The subversion of these normal processes in carcinogenesis is not yet understood, but mutation, gene amplification, pro- motor insertion, translocation and gene rearrangements resulting in inappropriate expression have all been implicated. ${ }^{47}$ Furthermore, several consistent chromosome abnormalities entailing oncogenes are associated with cancer. ${ }^{48}$ The Philadelphia (Ph) chromosome $\mathrm{C}^{49}$ is a common finding in chronic myeloid leukaemia and results from a 9:22 translocation. The $c-a b l$ oncogene is located near the breakpoint. The c-myc gene undergoes translocation from chromosome 8 to 14 in Burkitt's lymphoma with possible activation mediated at the immunoglobulin locus. ${ }^{35}$ Oncogenes, which do not have viral homologues, have now been found close to known breakpoints associated with a number of malignant diseases. $^{850}$

Malignant transformation of polyps in patients with familial polyposis is inevitable, ${ }^{3}$ and the disease is undoubtedly inherited where genetic factors have been postulated, ${ }^{24}$ although specific chromosomal lesions have not been observed. There is considerable individual variation in the age at which the florid malignant phenotype develops, however, and a number of specific genetic lesions occurring randomly in time within a susceptible genome may be responsible. Evidence for multiple functional genetic abnormalities in malignant transformation is forthcoming from both experimental ${ }^{45}$ and clinical data. A study on 54 patients with a range of 20 different malignant tumours has shown that more than one cellular oncogene was transcriptionally active. ${ }^{14}$ Furthermore, in most of the 14 patients in whom it was possible to study both normal and malignant tissue from the same organ there was increased transcriptional activity of oncogenes in the malignant tissue. Other studies have shown that ras genes are overexpressed in colonic polyps and carcinoma, ${ }^{15}$ and abnormalities of the myc gene family have been reported in several human malignant diseases, ${ }^{9-11} 16$ including colonic carcinoma. ${ }^{46}$ The results of this immunocytochemical study are very interesting in this context as they have shown an abnormal subcellular distribution of p62 $2^{\mathrm{c}-\mathrm{myc}}$ associated with both the known pre- 
malignant and overtly neoplastic colonic tissue. While we are not suggesting that this abnormal expression of $\mathrm{p} 62^{\mathrm{c}-\mathrm{myc}}$ is an absolute prerequisite for formation of adenoma, it is possible that the genetic defect in familial polyposis may, at least in part, produce a susceptibility for the c-myc gene to be overexpressed.

We thank Professor Austin Gresham for support and encouragement. This work was partially funded by the Medical Research Council and the Ludwig Institute for Cancer Research.

\section{References}

1 Mckusic VA. Genetic factors in intestinal polyposis. JAMA 1962;182:271.

2 Veale AMO. Intestinal polyposis. London: Cambridge University Press, 1965.

3 Ashley DJB. Colonic cancer arising in polyposis coli. J Med Genet 1969;6:376-8.

4 Medline A, Farber E. The multi step theory in neoplasia. In: Anthony PP, MacSween RNM, eds. Recent advances in histopathology. Edinburgh: Churchill Livingstone, 1981:19.

5 Lipkin M. Measurement of cell proliferation and associated risk factors in the identification of population groups with increased susceptibility to colonic cancer. In: Appleton DR, Sunter JP, Watson AJ, eds. Cell proliferation in the gastrointestinal tract. London: Pitman Medical, 1980:327.

6 Descher EE, Lipkin M. Proliferative patterns in colonic mucosa in familial polyposis coli. Cancer 1975;35:413-8.

7 Bishop JM. Viral oncogenes. Cell 1984;32:23-36.

8 Bishop JM. Trends in oncogenes. Trends in Genet 1984;1:245-9.

9 Schwab M, Alitalo K, Klempenauer KH, et al. Amplified N-myc with limited homology to myc cellular oncogene is shared by human neuroblastoma cell lines and a neuroblastoma tumour. Nature 1983;305:245-8.

10 Lee WW, Murphee AL, Benedict WF. Expression and amplification of the $\mathrm{N}-m y c$ gene in primary retinoblastoma. Nature 1984;309:458-60.

11 Little CD, Nau MM, Carney DN, Gazdar AF, Minna JD. Amplification and expression of the c-myc oncogene in human lung cancer cell lines. Nature 1983;306:194-6.

12 Nau MM, Brooks BJ, Battey J, et al. L-myc, a new myc related gene amplified and expressed in human small cell lung cancer. Nature 1986;318:69.

13 Seeger RC. Association of multiple copies of the N-myc gene with rapid progression of neuroblastoma. $N$ Eng $J$ Med 1985;313:1111-6.

14 Slamon DJ, Dekerion JB, Verma IM, Cline MJ. Expression of cellular oncogenes in human malignancies. Science 1984; 224:256-62.

15 Spandidos DA, Kerr IB. Elevated expression of the human ras oncogene family in premalignant tumours of the colorectum. Br J Cancer 1984;49:681-8.

16 McCarthy DM, Rassool FV, Goldman JM, Graham SV, Binnie GD. Genomic alterations involving the c-myc proto-oncogene locus during the evolution of a case of chronic granulocytic leukaemia. Lancet 1984;ii:1362-5.

17 Riou G, Barrois M, Tordjman I, Dutronquay V, Orth G. Presence de genomes de papillovirus et amplification des oncogenes c-myc et c-Ha-ras dans des cancers envahissants du col de l'uterus. CRC Acad Sc Paris 1985;299:575-80.

18 Rothberg PG, Erisman MD, Diehl RE, Roviatti UG, Astrin SM. Structure and expression of the oncogene c-myc in fresh tumour material from patients with heamopoetic malignancies. Mol Cell Biol 1984;4:1096-103.
19 Downward J, Yardem Y, Mayes E, et al. Close similarities of epidermal growth factor receptor and v-erb $\mathrm{B}$ oncogene protein sequences. Nature 1984;307:521-7.

20 Doolittle RF, Hunkerpiller MW, Hood LE, et al. Simian sarcoma virus onc gene, $v$-sis, is derived from the gene (or genes) encoding a platelet derived growth factor. Science 1983; 211:275-6.

21 Waterfield MD, Scrace GT, Whittle N, et al. Platelet derived growth factor is structurally related to the putative transforming protein $\mathrm{p} 28^{\mathrm{sis}}$ of simian sarcoma virus. Nature 1983;304:35-9.

22 Scherr CJ, Rettenmier CW, Sacca R, Roussel MF, Look AT, Stanley ER. The c-fms proto-oncogene product is related to the receptor for the mononuclear phagocytic growth factor, CSF 1. Cell 1985;41:665-76.

23 Wakelman MJO, Davies SA, Houslay MD, McKay I, Marshall CJ, Hall A. Normal $\mathrm{p} 21^{\mathrm{N}-\text { ras }}$ couples bombesin and other growth factors to inositole phosphate production. Nature 1986;323:173-6.

24 Kelly K, Cochran BH, Stiles CD, Leder P. Cell specific regulation of the c-myc gene by lymphocyte mitogens and platelet derived growth factor. Cell 1983;35:603-10.

25 Kelly K, Cochran BH, Stiles CD, Leder P. The regulation of c-myc by growth signals. Curr Top Microbiol Immun 1984;113:117-26.

26 Rabbitts PH, Watson JV, Lamond A, et al. Metabolism of c-myc gene products: $c-m y c$ mRNA and protein expression in the cell cycle. Embo $J$ 1985;4:2009-15.

27 Hann SR, Thompson CB, Eisenman RN. c-myc oncogene protein is independent of the cell cycle in human and avian cells. Nature 1985;314:366-9.

28 Greenberg ME, Ziff EB. Stimulation of 3T3 cells induces transcription of the c-fos proto-oncogene. Nature 1984;311:433-8.

29 Makino R, Hayashi KA, Sugimura T. c-myc is induced in rat liver at a very early stage of regeneration or by cycloheximide treatment. Nature 1984;310:697-8.

30 Muller R, Bravo R, Burckhardt J, Curran T. Induction of c-fos gene and protein by growth factors preceeds activation of c-myc. Nature 1984;312:716-20.

31 Thompson CB, Challoner PB, Neiman PE, Groudine M. Levels of c-myc oncogene mRNA are invariate throughout the cell cycle. Nature 1985;314:363-6.

32 Pfeiffer-Ohlsson S, Goustin AS, Rydnert J, et al. Spatial and temporal pattern of cellular -myc oncogene expression in developing human placenta; implications for embryonic cell proliferation. Cell 1984;38:585-96.

33 Pfeiffer-Ohlsson S, Rydnert J, Goustin AS, Larsson E, Betshottz C, Ohlsson R. Cell type specific pattern of myc proto-oncogene expression in developing human embryos. Proc Natl Acad Sci USA 1985;82:5050-4.

34 Studzinski GP, Brelvi ZS, Feldman SC, Watt RA. Participation of c-myc in DNA synthesis of human cells. Science 1986; 234:467-70.

35 Hamlyn PH, Rabbitts TH. Translocation joins the c-myc and the immunoglobulin $\gamma_{1}$ genes in Burkitt's lymphoma revealing a third exon in the c-myc oncogene. Nature 1983;304:135-9.

36 Stewart J, Evan GI, Watson JV, Sikora KE. Detection of the $\mathrm{c}-\mathrm{myc}$ oncogene product in colonic polyps and carcinomas. $\mathrm{Br}$ J Cancer 1986;53:1-6.

37 Sikora K, Evan G, Stewart J, Watson JV. Detection of the c-myc oncogene product in testicular cancer. Br J Cancer 1985; 52:171-6.

38 Watson JV, Sikora KE, Evan GI. A simultaneous flow cytometric assay for c-myc oncoprotein and cellular DNA in nuclei from paraffin embedded material. J Immunol Methods 1985; 83:179-92.

39 Watson JV, Stewart J, Evan G, Ritson A, Sikora K. The clinical significance of flow cytometric c-myc oncoprotein quantitation in testicular cancer. Br J Cancer 1986;53:331-7.

40 Elias-Jones J, Hendy-Ibbs P, Cox H, Evan GI, Watson JV. Cervi- 
cal brush biopsy specimens suitable for DNA and oncoprotein analysis using flow cytometry. J Clin Pathol 1986;39:577-81.

41 Hendy-Ibbs P, Cox H, Evan GI, Watson JV. Flow cytometric quantitation of DNA and c-myc oncoprotein in archival biopsies of uterine cervix neoplasia. Br J Cancer 1987;55:275-82.

42 Evan GI, Lewis GK, Ramsay G, Bishop JM. Isolation of monoclonal antibodies specific for human and mouse protooncogene products. Mol Cell Biol 1985;5:3610-16.

43 Evan GI, Hancock DC. Studies on the interaction of the human c-myc protein with cell nuclei: $\mathbf{p} 62^{\mathrm{c}-\mathrm{myc}}$ as a member of a discrete subset of nuclear proteins. Cell 1985;43:253-61.

44 Randall WB, Bish T, Canon LA, Dowdle MA, Randall GL, Skolnick G. Dominant inheritance of adenomatous colonic polyps and colorectal cancer. $N$ Engl J Med 1985;312:1540-3.

45 Land H, Parada LF, Weinberg RA. Tumorigenic conversion of primary embryo fibroblasts requires at least two cooperating oncogenes. Nature 1983;304:596-602.
46 Sikora K, Chan S, Evan G, et al. c-myc oncogene expression in colorectal cancer. Cancer 1987;59:1289-95.

47 Watson JV. Oncogenes, cancer and analytical cytology. Cytometry 1986;7:400-14.

48 Gilbert F. Chromosome aberrations and oncogenes. Nature 1983;303:475.

49 Rowley JD. A new consistent chromosomal abnormality in chronic myelogenous leukaemia identified by quinacrine fluorescence and Giemsa staining. Nature 1973;243:290-3.

50 Varmus HE. The molecular genetics of cellular oncogenes. Ann Rev Genet 1984;18:553-612.

Requests for reprints to: Dr JV Watson, MRC Clinical Oncology and Radiotherapeutics Unit, Medical Research Council Centre, Hills Road, Cambridge CB2 2QH, England. 